Konferans Bildirisi

\title{
21. YY Okuryazarlığı: Öğretmen Adaylarının Medya Algılarına Genel Bir Bakış
}

\author{
Fisun Bozkurt (Dr. Öğr. Üyesi) \\ Pamukkale Üniversitesi Eğitim Fakültesi \\ fisunbozkurt@pau.edu.tr \\ Deniz Çoşkun (Öğr. Gör.) \\ Pamukkale Üniversitesi Eğitim Fakültesi \\ dcoskun@pau.edu.tr
}

Başvuru Tarihi: 19.01.2018

Yayına Kabul Tarihi: 05.06.2018

Yayınlanma Tarihi: 30.07.2018

\section{Öz}

Bugün yaşadığımız dünya, çoğumuzun çocukluğumuzdan hatırladığı dünyadan çok farklıdır. 21. yüzyıl, medya tarafından bombalanan, teknolojik olarak bağımlı ve küresel olarak bağlantılı bir dünyadır. Bilgilerin çoğunun yüksek yapılandırılmış görsel imajlardan, karmaşık ses düzenlemelerinden ve çoklu ortam biçimlerinden oluştuğu, basılı kaynaklardan gelen bilgilerin ise daha az olduğu bir multimedya çağında yaşıyoruz. Bu nedenle, öğrencilere sadece harf ve rakamlarla okuma ve yazma öğretmek artık yetersizdir. Günümüzde çocuklar internetle birlikte evde ve okulda medyayla daha fazla temas halinde bulunmaktadır. Bu nedenle onlarda medyanın işleyişini değerlendirebilmeleri için yeni beceriler ve yetkinlikler geliştirilmesi önem kazanmıştır. Türkiye'de İlköğretim düzeyinde bu misyon sosyal bilgiler öğretmenlerine yüklenmiştir. Bu amaçla çalışmada Medya Okuryazarlığı dersini alan sosyal bilgiler öğretmen adaylarının medya okuryazarlığını nasıl algıladığı, öğretmen adaylarının kullandığı meteforlardan yola çıkılarak ortaya konulmaya çalışılmıştır. Bu çalışma nitel araştırma desenlerinden olgu bilime (fenomenoloji) göre desenlendirilmiştir. Araştırmanın çalışma grubunu 20162017 eğitim öğretim yılında medya okuryazarlığı dersini almış olan 74 sosyal bilgiler öğretmen adayı oluşturmaktadır. Bu çalışmanın bulguları, çalışmaya katılan öğretmen adaylarının Medya Okuryazarlığı Merkezinin belirlediği 5 temel kavram hakkında yeterli farkındalığa sahip olmadığını ortaya koymuştur. Ayrıca çalışmada, medya okuryazarlığı algısının kişiye göre değiștiği ancak öğrencilerin medya okuryazarlığının eleștirel analiz becerisi olduğu konusunda hem fikir oldukları bulgusuna ulaşılmıştır. $\mathrm{Bu}$ açıdan değerlendirdiğimizde medya okuryazarlığı öğrencilere eleștirel düşünme becerilerini geliștirmede yardımcı olan geniş bir laboratuvar sunmaktadır.

Anahtar Kelimeler: Medya okuryazarlığı, medya eğitimi, sosyal bilgiler öğretmen adayları.

Bu çalışma 4-6 Mayıs 2017 tarihinde Denizli/Türkiye'de düzenlenen IV. International Eurasian Educational Research Congress'te, "21st century literacy: An overview of teacher candidates" başlığıyla sunulan bildiridir. 
Conference Paper

\title{
Literacy for the 21st Century: An Overview Prospective Teachers' Media Perception
}

\author{
Fisun Bozkurt (Asst. Prof. Dr.) \\ Pamukkale University Faculty of Education \\ fisunbozkurt@pau.edu.tr \\ Deniz Çoşkun (Lect.) \\ Pamukkale University Faculty of Education \\ dcoskun@pau.edu.tr
}

Date Received: 19.01.2018

Date Accepted: 05.06.2018

Date Published: 30.07.2018

\begin{abstract}
Nowadays, we have experienced a world, which is more characteristic than the world that most of us recall from our past. The new word of 21st century, soaked with media, depending on the technology, and linked globally, is an intricate multimedia age with the information mostly comes from visual images, of sound arrangements, and in multiple media formats, all of which complexly constructed to manipulate us. Hence, the students have not educated only with letters and numbers but also with new media tools. Nowadays it is important to develop new skills and competencies to the children, who are in contact with media at home and school by internet more than before, to be able to evaluate the functioning of the media. In Turkey at primary level this mission has been uploaded to social studies teachers. For this purpose, it has been attempted to find out how the social studies prospective teachers are perceived the media literacy from the metaphores used by them. This study is a descriptive study based on qualitative data and designed according to phenomenology which is the qualitative research designs. The sample group consists of 74 social studies prospective teachers, who were taking the Media Literacy course, during the 20162017 academic year at a state university education faculty. Findings of this study revealed that the prospective teachers who participated in the study did not have enough awareness about the 5 basic concepts determined by the Media Literacy Center. In addition it has been found that the perception of media literacy changes according to the individual but it can be said that they all agree that media literacy is a critical analysis skill. From this point of view, media literacy offers a wide range of laboratories that help students develop critical thinking skills.
\end{abstract}

Keywords: Media literacy, media education, social studies prospective teachers. 


\section{Giriş}

Bugün yaşadığımız dünya, çoğumuzun çocukluğumuzdan hatırladığı dünyadan çok farklıdır. 21. yüzyıl medya tarafından bombalanan, teknolojik olarak bağımlı ve küresel olarak bağlantılı bir dünyadır. Küresel bilgi toplumumuzda, öğrencilere sadece harf ve rakamlarla okuma ve yazma öğretmek yetersizdir. Bireylerin aldığ bilgilerin çoğunun tipik olarak yüksek yapılandırılmış görsel görüntülerden, karmaşık ses düzenlemelerinden ve çoklu ortam biçimlerinden oluştuğu, basılı kaynaklarından gelen bilgilerin ise daha az olduğu bir multimedya çağında yaşıyoruz (Kellner ve Share, 2007).

"Okuryazarlık" terimi düşünüldügünde, genellikle akla gelen şey; okuma, yazma, konuşma ve dinlemedir. Bunlar gerçekten okuryazarlığın temel unsurlarıdır. Fakat günümüzde insanlar günlük hayatta çok farklı ifade ve iletişim biçimleri kullandıklarından, okuryazarlık kavramı, topluma tam olarak katılabilmek için sembol sistemleri aracılığıyla anlamı paylaşma yeteneği olarak tanımlanmaya başlamıștır. Benzer şekilde, "metin" terimi de dil, hareketli ve hareketsiz görüntüler, grafik tasarım, ses, müzik ve etkileșim gibi sembol sistemlerini kullanan sabit ve somut formdaki herhangi bir ifade veya iletişim biçimi olarak anlaşılmaya başlanmıştır. 50 yıldan fazla bir süredir yeni metin türleri ve yeni okuryazarlık türleri ortaya çıkmaktadır. Bunlar arasında bilgi okuryazarlığı, medya okuryazarlığı, medya eğitimi, görsel okuryazarlık, haber okuryazarlığı, sağlık medya okuryazarlığı ve dijital okuryazarlık gibi terimler bulunmaktadır. $\mathrm{Bu}$ birbiriyle ilişkili terimler, çağdaş toplumda başarı için gerekli olan yeni yeterlilikler kümesini tanımlamaktadır (Hobbs, 2010). Benzer şekilde Yeni Medya Konsorsiyumu (2005) tarafından sunulan 21. yüzyıl okuryazarlığı; işitsel, görsel ve dijital okuryazarlığın üst üste geldiği yetenek ve beceriler kümesi olarak tanımlanmaktadır. Bu beceriler kümesi; görüntü ve seslerin gücünü anlama, bu gücü tanıma ve kullanma, dijital medyayı manipüle etme ve dönüştürme, bunları yaygın bir şekilde dağıtma ve kolayca yeni biçimlere uyarlamayı kapsamaktadır (Oxstrand, 2009).

Medya Okuryazarlığı eğitime 21. yüzyıl yaklaşımıdır. Medya Okuryazarlığı eğitimi öğrencilere çeşitli biçimlerde mesajlara erişmek, analiz etmek, değerlendirmek ve oluşturmak için bir çerçeve sunar. Medya okuryazarlığı, medyanın toplumdaki rolünün yanı sıra demokrasilerde vatandaş olabilmek için gerekli olan sorgulama ve kendini ifade etme gibi temel becerilerin kazanılmasını sağlar (Thoman ve Jolls, 2008). Teknoloji, medya ve toplumdaki değişimler, öğrencilerin ve vatandaşların demokratik bir toplumda aktif katılımcılar olabilmeleri, medya mesajlarını doğru şekilde okumaları ve medyayı kendileri üretebilmeleri için eleştirel medya okuryazarlığının geliştirilmesini gerektirmektedir (Kellner ve Share, 2005).

Medya okuryazarlığı, kitle iletişiminin ve popüler kültürün farklı biçimlerini içerecek şekilde okuryazarlık kavramını genişletir ve aynı zamanda medya ile izleyiciler, bilgi ve güç arasındaki ilişkileri eleştirel bir şekilde analiz etmek için eğitim potansiyelini derinleştirir. Ayrıca, medya kodlarıve konvansiyonlarını, kalıplaşmış, baskın değerleri ve ideolojileri eleştirme becerilerini ve medya metinlerinin oluşturduğu çoklu anlam ve mesajları yorumlama becerilerini analiz etmede yetkinlik kazandırmayı içerir. Medya okuryazarlığı, medya içeriklerinin ayırt edilmesi ve değerlendirilmesine, medya biçimlerini eleştirel bir şekilde incelemeye, medya etkilerini ve kullanımlarını araştırmaya, medyayı akıllıca kullanmaya ve alternatif medya oluşturmaya yardımcı olur (Kellner ve Share, 2007). "Bu bağlamda medya okuryazarlığı sadece izleyicinin 
medyayı bilinçli okumasına katkı yapmakla kalmamakta, etki alanı, insanın özgürce kendini ifade etmesi, toplumsal hayata daha aktif ve yapıcı katılımı, yerel, ulusal ve kamusal medyanın iyileştirilmesiyle ilgili hareketleri desteklemek için bilinç oluşturma gibi çeşitli konulara kadar genişletilebilir" (Arık, 2006). Son zamanlarda, medya okuryazarlığı, demokrasi ve aktif vatandaşlık meseleleriyle giderek bağlantılı hale gelmiştir (İnceoğlu, 2007; Türkoğlu, 2007). Medya okuryazarlığının önemli bir boyutu da, medyanın geniş sosyal ve politik etkilerinin olduğunun farkında olunmasıdır. Kitle iletişim araçları, toplumun değerlerini ve tutumlarını meşrulaştırmaya hizmet eder. Medya ayrıca, medeni haklardan terörizme kadar küresel olaylar ve meseleler hakkında toplumun bilgilendirilmesinde de önemli bir role sahiptir. Medya eğitimi, medyanın çocukların kendi algı ve düşüncelerini filtrelediğini, popüler kültürü şekillendirdiğini ve kişisel tercihlerini nasıl etkilediğini fark etmelerine yardımcı olmalıdır. Medya eğitimi, çocuklara medya içeriğinin amaçlarını yansıtma becerisi, istenmeyen, saldırgan veya zararlı olabilecek medya içeriğini ve hizmetlerini tanımlama, bunlardan kaçınma ve bunlara meydan okuma yeteneği kazandırmalıdır (NAMLE, 2009).

Modern dünyada medya eğitimi, medya materyallerinin yardımıyla medya ile etkileşim kültürünün şekillenmesini, yaratıcılığın, iletişim becerilerinin, eleştirel düşüncenin, medya metinlerini algılamanın, yorumlamanın, analiz ve değerlendirmenin geliştirilmesini, medya teknolojisini kullanarak kendi kendini ifade etmenin farklı biçimlerini öğretmeyi amaçlayan kişiliğin gelişim süreci olarak tanımlanabilir. Medya okuryazarlığı, bu sürecin bir sonucu olarak, bireyin televizyon, radyo, video, film, basın ve internet tarafından sağlanan bilgi alanlarının fırsatlarını aktif olarak kullanmasına yardımcı olur. Bu eğitim kapsamında ilk olarak, kişinin eleștirel düşünme becerilerini ve kişisel özerkliğini geliștirmek hedeflenmektedir. İkinci olarak, farklı biçim ve türlerdeki medya metinlerini (metinlerin ahlaki çıkarımları ve sanatsal özellikleri de dahil olmak üzere) algılama, anlama, analiz etme ve değerlendirme yeteneklerini geliştirmek hedeflenmektedir. Ve üçüncü olarak ta, öğrencilerin medya ile denemeler yapması, kendi medya ürünlerini veya metinlerini oluşturabilmesi hedeflenmektedir (Fedorov, 2015).

Avrupa Medya Okuryazarlığı Merkezi'nin (Euorpean Centre For Media Literacy ECML akt. Pekman, 2007) medya okuryazarlığına yönelik bir eğitim programının amacını; "Medyanın fikir, bilgi ve haberi bir başkasının bakış açısıyla nakletmek üzere kurduğunu, duygusal etki oluşturmak için özel tekniklerin kullanıldığını, medyanın bazı kişilerin yararına çalıştığını bazılarını ise dışladığını anlamak, medyadan kimin yararlandı̆̆ı, kimin neden dışlandığı sorularını sormak ve cevabını bulmak, alternatif bilgi ve eğlence kaynakları aramak, medyayı kendi yararı ve zevki için kullanmak, edilgen olmak yerine aktif olmak, yeni öğrenme kültürü dijital okuryazarlı̆ga hazırlanmak" şeklinde açıklamaktadır. Yani medya okuryazarlığı, kaynağı her ne olursa olsun, her okuduğu, duyduğu ya da gördüğüne inanmayıp, bu bilgileri eleştirel bakış açısıyla değerlendirebilen bireyler yetiştirmeyi hedeflemektedir.

Gelişmekte olan multimedya ortamında medya okuryazarlığı tartışmasız her zamankinden daha önemlidir. Medya okuryazarlığı tüketiciler ve yurttaşlar olarak teknoloji yoğun dünyamızda yaşam için gerekli bir beceri haline gelmiştir. Medya eğitimi, gençlerin medyayı tüketiciler olarak yorumlamalarını, bilinçli seçimler yapmalarını, aynı zamanda eleștirel ve yaratıcı kapasiteye sahip medya üreticileri haline gelmelerini ve toplumda daha güçlü katılımcılar olmalarını mümkün kılmak 
için hem eleştirel anlayış hem de aktif katılımı geliştirmeyi amaçlamalıdır (Oxstrand, 2009). UNESCO, Avrupa Komisyonu, Avrupa Parlamentosu ve AML, CML ve NAMLE gibi birçok medya kuruluşu, medya eğitiminin dünyadaki her vatandaşın temel haklarından biri olduğunu ve bu eğitimin, çocukların dünyayı daha iyi anlamalarına ve demokratik kültürel yaşama katılmalarına yönelik olduğuna vurgu yapmışlardır. Başka bir deyişle medya eğitimi, çocuklara medyayı demokratik haklar ve yurttaşlık sorumluluğu bağlamında etkili bir şekilde kullanma becerisi kazandırmayı amaçlamaktadır (Oxstrand, 2009). Benzer şekilde Kellner ve Share'e (2005) göre de eleștirel medya okuryazarlığı, çocukların adaletsizlikleri yıkma, kendi seslerini ifade etme ve daha iyi bir toplum yaratma çabası içinde özneler olmalarına yardımcı olacak araçlar ve bir çerçeve sunmaktır. AB Parlamentosu da (2005), medya okuryazarlığının bilgi ve iletişim toplumunda önemli bir beceri olduğunu ve medya okuryazarlığının, bütün okul düzeylerinde müfredatın ayrılmaz bir parçası olması ve öğretmen eğitiminin zorunlu bir bileșeni olması gerektiğini belirtmiștir. Türkiye'de İköğretim düzeyinde medya okuryazarlığı dersi sosyal bilgiler öğretmenleri tarafından yürütülmektedir. Bu amaçla çalışmada Medya Okuryazarlığı dersini alan sosyal bilgiler öğretmen adaylarının medya okuryazarlığını nasıl algıladığı ve öğretmen adaylarının kullandığı meteforlardan yola çıkılarak, Medya Okuryazarlığı Merkezinin (CML, 2005) belirlediği 5 temel anahtar kavramdan hangilerinin farkında olduğu ortaya konmaya çalışılmıştır.

\section{Yöntem}

\subsection{Araştırmanın Deseni}

$\mathrm{Bu}$ çalışma nitel verilere dayalı olarak gerçekleştirilmiş betimsel bir çalışmadır. Çalışma, nitel araştırma desenlerinden olgu bilime (fenomenoloji) göre desenlendirilmiştir. "Olgu bilim deseni farkında olunan, ancak derinlemesine ve ayrıntılı bir anlayışa sahip olunamayan olgulara odaklanmaktadır. Olgular yaşadığımız dünyada olaylar, deneyimler, algılar, yönelimler, kavramlar ve durumlar gibi çeşitli biçimlerde karşımıza çıkabilmektedir. Ancak bu tanışıklık olguların tam olarak anlaşıldığı anlamına gelmez. Insana tümüyle yabancı olmamakla birlikte, onun tam anlamıyla kavrayamadığı olguları araştırmayı amaçlayan çalışmalar olgu bilim kapsamına dahil edilir." (Yıldırım ve Şimşek, 2013, 78). “Cü̈kü olgu bilim betimlemenin ötesinde araştırmacıların deneyimlerin anlamı ile ilgili yorum yaptığı süreçtir" (Van Maanen, 1990, 26, akt. Creswell, 2013, 80). "Amaç gerçek ya da hayal ürünü, ampirik olarak ölçülebilir ya da öznel olarak hissedilebilir olsun, kendini bilince sunan herhangi bir şey, potansiyel olarak fenomenolojinin ilgi konusudur" (Patton, 2014, 104).

\subsection{Araştırmanın Örneklemi}

Katılımcıların belirlenmesinde amaçlı örneklem yöntemi kullanılmıştır. Araştırmanın çalışma grubunu 2016-2017 eğitim öğretim yılında medya okuryazarlığı seçmeli dersini almış olan, 47 erkek, 27 kadın toplam 74 sosyal bilgiler öğretmen adayı oluşturmaktadır.

\subsection{Veri Toplama Aracı ve Veri Analizi}

Araştırma verileri öğretmen adaylarına yöneltilen;

Medya ..gibidir; çünkü sorusuna verdikleri cevaplardan elde edilmiştir. Medya Okuryazarlığı dersi sonunda öğretmen adaylarının 
Medya Okuryazarlığı Merkezinin belirlediği 5 temel anahtar kavram hakkındaki farkındalıklarını belirlemek amacıyla öğretmen adaylarının, medyayı metafor kullanarak tanımlamaları ve seçtikleri meteforun nedenini açıklamaları istenmiştir.

Veriler betimsel analiz yöntemi kullanılarak analiz edilmiştir. Betimsel analiz aşamasında toplanan veriler Medya Okuryazarlığı Merkezince tanımlanmış kavramlar ve uygun temalara göre kodlanmıștır. Bu kodlar 74 öğretmen adayının yazılı yanıtları üzerinde doğrudan ve elde edilebilir anlamlarından yola çıkılarak tespit edilip, metin içinde işaretlenmiştir. Kodlanmış veriler benzerlikleri ve farklılıklarına göre incelenmiş ve gruplandırılmıştır.

\subsection{Geçerlik ve Güvenirlik}

Geçerlik ve güvenirlik sağlanması doğrultusunda medya okuryazarlığı merkezinin öne sürdügü beş temel anahtar kavram dikkate alınarak gruplandırılan veriler iki farklı araştırmacı tarafından değerlendirilmiştir. Öğretmen adayları tarafından üretilen 74 metafor ve açıklamalarını içeren cümlelerin incelenmesi sonucunda uygun kategorilere yerleştirilmiştir. Kategori ve metaforlar birbiriyle benzerlik ve farklılıkları doğrultusunda tekrar incelenmiştir. Örnek olarak, "sihirbaz" metaforu birinci araştırmacı tarafından birinci kategoriye ("medya mesajlarının tümü kurgulanmıştır") dahil edilirken, ikinci araştırmacı bu metaforu ikinci kategoriye ("Medya mesajları kendine özgü kurallar kullanılarak yaratıcı bir dille kurgulanmıştır") dahil etmiștir. Üzerine hemfikir ve ayrı görüş olarak ortaya çıkan metafor gruplandırmaları tespit edilerek Miles ve Huberman $(1994,64)$ tarafından geliştirilen "Güvenirlik = görüş birliği/görüş birliği + görüş ayrılığı x 100 formülü uygulanmıştır. Araștırmacılar arasındaki uyum \% 96 olarak tespit edilmiştir.

\section{Bulgular}

Çalışmaya katılan öğrenciler tarafından 74 metafor üretilmiștir. Üretilen metaforlarda öğrencilerin \%77'sinin (f=57) medya okuryazarlığının temelini oluşturan 5 temel kavramdan birine vurgu yaptığı görülmüştür. Ayrıca çalıșma verilerinin analizi sonucunda temel kavramlardan farklı olarak iki kategori daha elde dilmiştir. Bunlar; katılımcıların \%15'i (f=11) tarafından "Medyanın sınırsız/enegellenemez" olduğu, \%8'i $(\mathrm{f}=6)$ tarafından ise "Medyanın temel ihtiyaçlarımızdan" olduğu kategorileridir (Tablo 1).

Tablo 1: "Medya" kavramına yönelik metaforların frekans ve yüzde oranları

\begin{tabular}{|l|l|c|c|}
\hline Kategoriler: Beş Temel Kavram & Metaforlar & f & \% \\
\hline $\begin{array}{l}\text { Medya mesajlarının tümü } \\
\text { kurgulanmışır. }\end{array}$ & $\begin{array}{l}\text { Oyun hamuru, resimli kitap, } \\
\text { kapalı kutu, buz dağı, sinema } \\
\text { perdesi, sanal dünya, algı } \\
\text { değiştiren makina, akrep, } \\
\text { örümcek ağı, savaş, antibayotik, } \\
\text { hastalık, pusula, renkli balonlar, } \\
\text { nehir, insanlar, bıçak, ilaç, } \\
\text { pamukşeker, lunapark, yiyecek, } \\
\text { tren, sonu olmayan çukur }\end{array}$ & 28 & 38 \\
\hline $\begin{array}{l}\text { Medya mesajları kendine özgü } \\
\text { kurallar kullanılarak yaratıcı } \\
\text { bir dille kurgulanmıştır. }\end{array}$ & Sihirbaz & 1 & 1 \\
\hline $\begin{array}{l}\text { Aynı mesajı farklı kişiler farklı } \\
\text { şekilde algılayabilirler. }\end{array}$ & Gri renk, yarısı dolu bardak & 2 & 3 \\
\hline
\end{tabular}




\begin{tabular}{|l|l|c|c|}
\hline $\begin{array}{l}\text { Medyanın gizlenmiş değer } \\
\text { ve görüşleri vardır. }\end{array}$ & $\begin{array}{l}\text { Dünya, el feneri, deniz, okuma } \\
\text { yazma bilmeyenin resimli } \\
\text { kitap okuması, buzdağı }\end{array}$ & 7 & 9 \\
\hline $\begin{array}{l}\text { Medyadaki mesajların büyük } \\
\text { çoğunluğu kazanç ya da güç elde } \\
\text { edebilmek için düzenlenmiştir. }\end{array}$ & $\begin{array}{l}\text { Sarmaşık, ahtapot, sigara, bir } \\
\text { grup insan, kene, virüs, insan } \\
\text { zihnini ele geçirmekte kullanılan } \\
\text { bir araç, fabrika, bakteri, duygu, } \\
\text { mıknatıs, siyasetçiler, silah }\end{array}$ & 19 & 26 \\
\hline Diğer Kategoriler & Metaforlar & $\mathrm{f}$ & $\%$ \\
\hline Medya sınırsızdır/enegellenemez. & $\begin{array}{l}\text { Deniz yıldızı, çarkıfelek, orman, } \\
\text { okyanus, zincir, ahtapot, dünya }\end{array}$ & 11 & 15 \\
\hline Medya temel intiyaçlarımızdandır. & $\begin{array}{l}\text { Yemek ve su, vücut organları, } \\
\text { temel gereksinim, nefes } \\
\text { alma, sanal bir dünya }\end{array}$ & 6 & 8 \\
\hline Toplam & & 74 & 100 \\
\hline
\end{tabular}

Temel Kavram 1. Medya mesajlarının tümü kurgulanmıştır. Çalışmaya katılan öğrencilerin \%38'i (f=28) medyanın kurgulanmışlığı kavramına vurgu yapmıştır. Örnek metaforlar;

\begin{tabular}{ll}
\hline & Oyun hamuru kimin elindeyse ona \\
& istediği şekli verir. Mesela elma yapar. \\
Oizi yaptığı şeyin elma olduğuna inandırır. & Biz oyun hamurunu değil şekillenmiş \\
& halini görür ve onu doğru kabul ederiz. \\
\hline & Yalanı-doğru, kötüyü-iyi, vahşiyi-yahşi, \\
& zalimi-halim gösterebilir. İnsanları \\
nasıl istiyorsa o şekilde yönlendirebilir, \\
ilgın değiştiren makinabilir. Bu yüzden çok iyi bir \\
& medya okuryazarı olmalıyız \\
\hline
\end{tabular}

Öğrencilerin yapmış olduğu metaforlardan medya metinlerinin asla "doğal" şeyler olmadığının ve kurgulandığının farkında olduğu bulgusuna ulaşılmıştır. Ayrıca bu tema kapsamında öğrencilerin çoğunun (f=16) medyayı doğru okuyabilme becerisinin önemine ve medyaya eleştirel bir bakış açısı temelinde yaklaşılması gerektiğine vurgu yaptığı görülmektedir. Medya Eğitimi, çocuklara medya içeriğinin nasıl ve niçin üretildiğini anlama yeteneği sağlamalıdır. Medya eğitimi, aktif ve eleştirel bir katılımı teşvik etmeli ve aldığımız, yarattığımız mesajların içeriğine ilişkin bir sorgulamaya yol açmalıdır. Eleștirel bakıș açısını vurgulayan örnek metaforlar şunlardır;

\begin{tabular}{ll}
\hline & Hastalığın üstesinden gelmek için doktora \\
& gideriz, ilaç kullanırı. Medyayı etkin bir \\
Şekilde yönetebilmek fayda sağlayabilmek & için medya mesajlarını doğru okuyabilme \\
& kriterlerini yerine getirmeliyiz. \\
\hline & Bilinçli olarak bakıldığında ve incelendiğinde \\
& mükemmel bir şey. Fakat bu mükemmelliğin \\
& içeriğini sorgulayamıyorsak örümcek \\
Örüına yapışan küçük böcekler gibi & yapışıp örümceğe yem olabiliriz. \\
\hline
\end{tabular}

Temel Kavram 2 Medya mesajları kendine özgü kurallar kullanılarak yaratıcı bir dille kurgulanmıştır. Medya kendi kuralları ile yaratıcı bir dil kullanılarak oluşturulmakta ve kelimeler, müzik, renk, hareket, kamera açları ve çok daha fazlasını bir araya getirmek için yaratıcı bileșenler kullanmaktadır. Ancak çalışmaya katılan öğrencilerden sadece \% 1'i ( $\mathrm{f}=1$ ) bu kavrama ilișkin bir metafor kullanmıștır. Bu bulgudan, Medya Okuryazrlığı Merkezinin 2. Temel kavramının öğrenciler tarafından 
çok iyi anlaşılmadığı ve sınıfta bu kavramla ilgili yeterli açıklama ve etkinliklerin yapılmadığı sonucuna ulaşılabilir.

\begin{tabular}{ll}
\hline & Biz farkında olmadan yapılan küçük \\
& numaralarla insanları etkiler. Birçok \\
Sihirbaz & fikri aşılayabilir. O yüzden algılarımız \\
& hep açık olmalı, gerçekle, gerçek \\
& olmayanı anlayabilmeliyiz. \\
\hline
\end{tabular}

Bu meteforda her bir iletişim şeklinin kendine özgü yaratıcı bir dile sahip olduğu bizlerin yapılan hilelere ya da kullanılan taktiklere karşı daha fazla şüpheci davranmamız gerektiği belirtilmektedir.

Temel Kavram 3 Farklı kişilerverilen aynı mesajı farklışekilde algılayabilirler. Çalışmaya katılan öğrencilerden \% 3'ü (f=2) bu kavrama ilișkin metaforlar kullanmıșlardır.

\begin{tabular}{ll}
\hline \multirow{2}{*}{ Gri renk } & $\begin{array}{l}\text { Ne olduğu net değildir. İki şey vardır, } \\
\text { ama karışımdır. Her insan o karışımda } \\
\text { kendisiyle bağlantılı olarak neyi } \\
\text { görmek istiyorsa onu görür. }\end{array}$ \\
\hline Yarısı dolu bardak & Nasıl görmek istersen öyle görürsün. \\
\hline
\end{tabular}

Yukarıdaki iki metaforda da bireylerin medya metinlerinin çözümlenmesinde aktif rol oynadıkları ve kendi yaşantısına ait bir dizi deneyimi medya metinlerine getirerek özel bir anlam oluşturdukları ifade edilmektedir. Ancak çalışmada bu temel kavrama ilişkin sadece iki metefor elde edilmiştir. Bu bulgu, Medya Okuryazrlığı Merkezinin 3. Temel kavramının da öğrenciler tarafından çok iyi anlaşılmadığı ve sınıfta bu kavramla ilgili yeterli açıklama ve etkinliklerin yapılmadığı şeklinde yorumlanabilir.

Temel Kavram 4 Medyanın gizlenmiş değer ve görüşleri vardır. Çalışmaya katılan öğrencilerden \% 9'u (f=7) bu kavrama ilişkin metaforlar kullanmışlardır;

\begin{tabular}{ll}
\hline El feneri & $\begin{array}{l}\text { Neyi göstermek isterse onu göstermekte ustadır. } \\
\text { İstediğine ışık tutar yüceltir. İstemediğini göstermez. } \\
\text { Kimsenin o şeyin varlığından bile haberi olmaz. }\end{array}$ \\
\hline Buzdağı & $\begin{array}{l}\text { Görünenden fazlası vardır aslında, bize gösterilmek istenenler } \\
\text { ve asıl amaç/plan doğrultusunda yapılmak istenenler. }\end{array}$ \\
\hline $\begin{array}{l}\text { Okuma yazma bilmeyenin } \\
\text { resimli kitap okuması }\end{array}$ & $\begin{array}{l}\text { Kitabın sadece resimlerine bakarak bilgi edinir. Yani medyanın } \\
\text { ne işe yaradığını amaçlarını bilmiyorsak sadece resimlerin } \\
\text { anlattıklarını görürüz, alttaki mesajları okuyamayız. }\end{array}$ \\
\hline
\end{tabular}

$\mathrm{Bu}$ temel kavramla ilişkili olan metaforlardan öğrencilerin medya mesajlarının kurgulanmış oldukları için gerçek dünyayı yansıtmadığı, tüm medya metinlerinin mesajı yaratan kişi veya kişiler tarafından tasarlanmış olduğu ve yapılan seçimlerin mesajı yaratan kişi veya kişilerin değerlerini, tutumlarını ve fikirlerini taşıdıklarının farkında olduğu şeklinde yorumlanabilir.

Temel Kavram 5 Medyadaki mesajların büyük çoğunluğu gelir ya da güç elde edebilmek için organize edilmişlerdir. Çalışmaya katılan öğrencilerden \%26'sı (f=19) bu kavrama ilişkin metaforlar kullanmıștır;

\begin{tabular}{ll}
\hline & Her yerde eli kolu vardır. Bizi kolaylıkla \\
& sarıp esir alabilir. İzlediğimiz diziler, \\
haberler, reklamlar bizi bir düşüncenin, bir & ideolojinin esiri yapabiliyor. Biz ne kadar \\
& etkilenmek istemesek de o bizi etkiler. \\
\hline
\end{tabular}




\begin{tabular}{ll}
\hline \multirow{3}{*}{ Virüs } & $\begin{array}{l}\text { Virüs gibi her yere yayılır. Vücudun bütün } \\
\text { duyularına geçer. Onu ele geçirir, yönlendirir, } \\
\text { düşündürür, yıpratır, aldatır. Yararlı olanları } \\
\text { da vardır. Ama medya açısından çok değil. }\end{array}$ \\
\hline \multirow{3}{*}{ Kene } & $\begin{array}{l}\text { Insanlara yapışıp onlardan faydalanıyorlar. } \\
\text { Onları reklamlarla, reklamlardaki güzel } \\
\text { insanlarla etkileyip ürünlerini satıyorlar. } \\
\text { İnsanların intiyaçları olmasa bile. }\end{array}$ \\
\hline
\end{tabular}

Yapılan metaforlardan öğrencilerin bir kısmının, medya dünyasının çok büyük bir bölümünün para kazanmayı amaçlayan şirketler oldukları ve ayrıca mesaj yoluyla bireyleri güdüleme, yönlendirme eğilimine sahip oldukları konusunda farkındalığa sahip olduğunu söyleyebiliriz.

Kavram 6. Medya sinırsızdır/enegellenemez. Katılımclların \%15'i (f=11) medyanın dünya hakkında sınırsız ve engellenemez kaynaklar sağlamakta olduğunu belirtmiștir. Öğrenciler bu tema ile ilgili olarak aşağıdaki metaforları kullanmışlardır;

\begin{tabular}{ll}
\hline \multirow{2}{*}{ Deniz Yıldızı } & $\begin{array}{l}\text { Deniz yıldızı gibi bir yeri kesildiğinde } \\
\text { kendini kolayca yeniler. Medyada bir } \\
\text { sosyal ağ engellendiğinde başka bir } \\
\text { sosyal ağ kolayca oluşturulur. }\end{array}$ \\
\hline \multirow{3}{*}{ Deniz } & $\begin{array}{l}\text { Bilinmeyen keşfedilmeyen yerleri } \\
\text { çoktur. Büyük ve karmaşık olmasına } \\
\text { rağmen sahip olduğu ağlarla ulaştırmak } \\
\text { istediklerini mutlaka ulaştırır. }\end{array}$ \\
\hline
\end{tabular}

$\mathrm{Bu}$ temel kavramla ilgili yapılan metaforlarda öğrenciler, hergün isteyerek yada istemeyerek binlerce mesaj bombardımanına maruz kaldıklarının ve bunun da engellenemez olduğuna vurgu yapmaktadırlar.

Kavram 7. Medya temel ihtiyaçlarımızdandır. Öğrencilerin \%8'i (f=6) medyayı temel ihtiyaç olarak ifade etmektedirler ki bunu bir tür bağımlılık olarak yorumlayabiliriz.

\begin{tabular}{ll}
\hline Yemek ve Su & $\begin{array}{l}\text { Hayatımızdaki yeri çok fazladır. } \\
\text { Onsuz hiçbir şey yapamayız. }\end{array}$ \\
\hline \multirow{3}{*}{ Temel Gereksinim } & $\begin{array}{l}\text { İnsan yaşamı için gerekli besini almak } \\
\text { zorundadır. Medya da insanın temel } \\
\text { ihtiyaçlarından bazılarını karşılar. }\end{array}$ \\
\hline \multirow{3}{*}{ Nefes almaya } & $\begin{array}{l}\text { Çünkü hayatımızın her anında her nefes } \\
\text { alışımızda medya bizim yanımızda. } \\
\end{array}$ \\
& önümüze çıkan her boş zamanı \\
& internete girerek kullanıyoruz. \\
\hline
\end{tabular}

\section{Tartışma}

$\mathrm{Bu}$ çalışmada, çalışmaya katılan öğrencilerin \%77'sinin medya okuryazarlığı konsunda eleştirel bir anlayışa sahip olduğu bulgusuna ulaşılmıştır. Yapılan metafor analizi sonucunda sırasıyla öğrencilerin \%38'i “Medya mesajlarının tümünün kurgulandığını", \%1'i "Medya mesajlarının kendine özgü kurallar kullanılarak yaratıcı bir dille kurgulandığını", \%3'ü "Aynı mesajı farklı kişilerin farklı şekilde algılayabileceğini", \%9'u "Medyanın gizlenmiş değer ve görüşleri içerdiğini” ve \%26'sının ise "Medyadaki mesajların büyük çoğunluğunun kazanç ya da güç elde edebilmek için düzenlenmiş", olduğunun farkında olduğunu söyleyebiliriz.

Temel Kavram 1. Şeffaf Olmayan İlke: Tüm medya mesajları "kurgulanmıştır" Araștırmada, öğrencilerin \%38'inin Medya Okuryazarlığı Merkezinin birinci temel kavramı hakkında farkındalığa sahip olduğu bulgusuna ulaşılmıştır. Bu temel 
kavram, medya okuryazarlığının temelidir ve medyanın mesajları problemsiz ve şeffaf olarak sunma gücüne meydan okuma anlamına gelmektedir. Masterman (1994), medya eğitiminin temelinin "olmayan-şeffaflık" ilkesi olduğunu ileri sürmektedir. Olmayan șeffaflık kavramını "medya gerçekliği sunmaz, temsil eder" şeklinde açıklamaktadır. Medya, șeffaf pencereler veya dünyanın basit yansımaları gibi gerçekliği sunmaz, çünkü medya mesajları bir yapım/kurgu süreci ile oluşturulur, şekillendirilir ve konumlandırılır. Bu yapılandırma süreci, mesaja neyin dahil edileceği veya hariç tutulacağı ve gerçekliğin nasıl temsil edileceği hakkında birçok kararı içerir (Kellner ve Share, 2005).

CML (2005) medya okuryazarlığında "yazarlık" fikrini keşfetmenin, bir kitabın kapağında kimin adının ya da bir filmindeki tüm işlerden kimin sorumlu olduğunun bilinmesiyle yetinmek olmadığını belirtmiștir. Ayrıca Temel Kavram 1 kapsamında, tüm medyayla ilgili iki temel kavrayışa vurgu yapmıştır; "kurgulanmışlık" ve "seçim".

Birincisi, medya metinlerinin "gerçek" görünmelerine rağmen "doğal" olmadıklarının farkında olunmasını gerektirir. Medya metinleri, aynı binaların ve otoyolların bir araya getirilmesi gibi inşa edilir: bir plan yapılır, yapı taşları toplanır ve sıradan insanlara çeşitli işler yapmaları için ücret ödenir. Bunun anlamı ister gece haberlerini izlerken, ister sokakta bir panonun önünden geçerken ya da politik bir kampanyayı okurken, deneyimlediğimiz medya mesajlarının biri (ya da muhtemelen birileri) tarafından yazıldığı, görüntülerin çekildiği ve yaratıcı bir ekip tarafından hepsinin bir araya getirilerek düzenlendiğidir.

İkinci fikir ise, bu yaratıcı süreçte, "seçimlerin" yapılmasıdır. Yapılan seçimler mesajı yaratan kişi veya kişilerin değerlerini, tutumlarını ve fikirlerini kaçınılmaz olarak yansıtmaktadır. Ancak izleyici olarak bizler, sadece neyin kabul edildiğini görür, duyar veya okuruz.

Sonuç olarak, sadece birkaç kişi tarafından "kurgulanan" şey, geri kalanımız için soluduğumuz hava gibi "normal" hale gelir hatta bazen medya mesajlarını sorgulamadan kabul ederiz. Medya "gerçek" değildir ancak, insanları gerçek anlamda etkilemektedir çünkü, yaratımı yapanların vermiş oldukları her şeyi kendimiz için alıp anlamlandırırız. Medya metinleri ne kadar doğal görünürse o kadar başarılı olur. Örneğin; sahte görünen bir TV programını kimse izlemek istemez. Ama gerçek şudur ki, hepsi sahtedir - buna haberler de dâhildir (Jolls ve Thoman, 2008). Bu nedenle medya mesajlarını eleştirel sorgulama yoluyla kavramak medya okuryazarlığı için önemli bir başlangıç noktasıdır (Kellner ve Share, 2005).

Temel Kavram 2. Kodlar ve Kurallar: Medya mesajları kendine özgü kurallar kullanılarak yaratıcı bir dille kurgulanmıştır.

Çalışmaya katılan öğrencilerin sadece \%1'i ikinci temel kavram hakkında bir metafor yazmıştır. Bu çalışmanın bulguları öğrencilerin bu temel kavram hakkında farkındalığa sahip olmadığı ve bu konudaki temsil analizlerinin sınıfta yapılmadığı şeklinde yorumlanabilir. İkinci Temel Kavram kapsamında öğrencilerin, bir medya mesajının "formatını" araştırıp, bir mesajın oluşturulma şeklini, bir araya getirilmesinde kullanılan yaratıcı bileşenleri (kelimeler, müzik, renk, hareket, kamera açısı ve daha fazlasını) incelemesi hedeflenmektedir (CML, 2005).

İkinci temel kavram aynı zamanda işaretlerin ve sembollerin nasıl işlediğini göstermek için büyük ölçüde semiyotiklere dayanır. Semiyoloji, işaret ve sembolleri 
ve de işaret sistemindeki yapısal ilişkilerden anlamların toplumsal olarak nasıl üretildiğini çalışan bilimdir. Bu bilim medya okuryazarlığına büyük katkı sağlamaktadır. $\mathrm{Bu}$ temel kavramda öğrencilerin, düşündükleri veya hissettikleri şeylerden gördüklerini veya duyduklarını ayırd etmeleri beklenmektedir. Örneğin; televizyon ya da film gibi medyadaki sınıf, cinsiyet ve ırk temsilinin tartışılması, patronların, zenginlerin, erkeklerin ve beyaz insanların temsilinin aksine, işçiler, kadınlar ve farklı ten rengine sahip insanlar gibi alt grupların temsil edildiği kodların ve kalıp yargıların analizini gerektirir. Kadınların veya farklı ten rengine sahip insanların farklı temsil biçimlerinin analizi, medyada toplumsal cinsiyet ve irk temsillerinin nasıl inşa edildiği ve baskın negatif temsillerin nasıl doğal gösterildiğini öğrencilerin anlamasını sağlar. Sonuç olarak, bu temel kavram kapsamında öğrencilerin medya mesajlarının dünyaya açılan bir pencere olmayıp son derece kodlu yapılar olduğunu fark etmeleri sağlanmalıdır (Kellner ve Share, 2005).

Thoman ve Jolls (2008) Temel Kavram 2' nin amacını, öncelikle bir mesajın nasıl oluşturulduğunun fark edilmesi şeklinde açıklamıştır. Haberlerde dâhil olmak üzere, bugünün iletişiminin çoğunun görsel olarak bize gelmesi nedeniyle, öğrencilerin görsel iletişimin temellerini (aydınlatma, kompozisyon, kamera açısı, düzenleme, sahne kullanımı, beden dili, semboller, vb.) öğrenmeleri önemlidir. Bu tekniklerin kullanımı, bir mesajdan alabilecek anlamları etkilemektedir. Özellikle görsel dil olmak üzere medyanın dilbilgisi, sözdizimi ve metafor sistemini anlamak, sadece manipülasyona karşı daha duyarlı olmamıza yardımcı olmakla kalmaz, aynı zamanda medyayı inşa edilmiş bir "metin" olarak takdir etmemizi ve zevk almamızı sağlar. İkinci temel kavramı geliştirilmenin en iyi yolu, bunu öğrencilerin bizzat kendilerinin yapmalarıdır. Bu nedenle öğrencilere; bir kamu hizmeti duyurusu yapmaları, bir web sitesi oluşturmaları, bir pazarlama kampanyası geliştirmeleri gibi uygulamalar yaptırılabilir.

Temel Kavram 3. İzleyicilerin Kod Çözümü: Aynı mesajı farklı kişiler farklı şekilde algılayabilirler.

Çalışmada öğrencilerin \%3'ü bu kavrama yönelik metafor yazmıștır. Bu bulgu öğrencilerin üçüncü temel kavram hakkında da farkındalığa sahip olmadığı ve bu konuda kodlama ve kod çözme ile ilgili sınıfta yeterli açılklama ve etkinliğin yapılmadığı şeklinde yorumlanabilir. Birleşik Krallık'taki Birmingham Çağdaş Kültürel Çalıșmalar Merkezinin aktif izleyici kavramı, medya alıcılarını pasif alıcılar ve genellikle de kurbanlar olarak gören önceki teorilere meydan okumaktadır. Roland Barthes ve Umberto Eco, Hall (1980) tarafından geliştirilen semiyotik kavramlar üzerine inşa 'Kodlama/Kod çözme' ile ilgili çalışma medya metinlerinin üretici tarafından kodlanması ve bu kodların tüketiciler tarafından çözümlenmesi arasında bir ayrım yapılması gerektiğini vurgular. Bu ayrım, izleyicilerin kendi okumalarını ve anlamlarını üretme ve metinlerdeki kodları baskın ideolojiyle uyum içinde tercih edilen yöntemlerin yanı sıra, muhalif bakış açısıyla da çözmek için yeteneklerin geliştirilmesine vurgu yapar. Buna göre izleyici açıkça pasif değildir ve seçim yapabilir (Kellner ve Share, 2005).

Ang'de (2002, s. 180) izleyicilerin yorumladığı belirli bir metnin, içerikle tutarsız farklı şeyler de ifade edebileceğini vurgulamıştır. Ang'e göre öğrencilerin farklı kişilerin aynı mesajı farklı şekilde yorumlayabilmelerini görme yeteneği, çok kültürlü eğitim için önemlidir çünkü farklılıkları anlamak, yalnızca bir diğerini tolere etmekten fazlasını ifade eder. Örneğin, bir araştırmada ABD televizyon dizisi 
Dallas'ın çeşitli ülkelerdeki insanlar için çok farklı kültürel anlamları olduğunu ve kodları Hollandalı ve İsrailli izleyicilerin Amerikan izleyicilerinden çok farklı bir şekilde çözümlediğini göstermiştir. Aynı şekilde, cinsiyet, ırk, sınıf ya da cinsellik gibi farklı konular, pozisyonları farklı okumalar üretecek ve bir medya metnini kavramak farklı izleyici perspektiflerinin bakış açısıyla yorumlanması ile zenginleştirilecektir.

Bu konuda benzer şekilde CML (2005) Temel Kavram 3'ün, iki önemli düşünceyi içerdiğini belirtmiştir. Bunlar: farklılıklarımızın medya mesajlarını yorumlamada farklı anlayışlar, benzerliklerimizin de ortak anlayışlar yaratmasıdır. Aynı filmi izleyen iki kişinin aynı filmi görmediği veya radyoda aynı şarkıyı duymadığını; ebeveynler ve çocukların bile aynı TV şovunu izlemelerine rağmen aynı şeyleri görmediklerini belirtmiştir. Başka bir deyişle her bir izleyicinin kendi yaşantısına ait bir dizi deneyimi medya metinlerine getirerek (yaş, cinsiyet, eğitim, kültürel birikimler vb.) birleștirdiklerini ve özel bir anlam oluşturduklarını belirtmiştir. Ayrıca, izleyicilerin medya metinlerinin açıklanmasında aktif bir rol oynadıklarını, bunun bilincinde olmasakta her birimizin zihninin, hatta küçük çocuklarda, gördüklerimiz, duyduğumuz veya okuduğumuz şeylerin "anlamlandırılması" için sürekli çalışıyor olduğunu belirtmiştir.

Farklılıklarımız, birden fazla yorumlamanın duyulmasına, farklı kültürlere ve azınlık görüşlerine duyulan saygının artmasına ve çok kültürlü bir dünyada bu kritik becerinin gelişmesine katkı sağlarken, benzerliklerimiz de, medya üreticilerinin fikirlerini etkilemek veya daha genel olarak bir șey satmak için nüfusun farklı kesimlerini "hedef aldıklarını" anlamak açısından önemlidir.

Son olarak, bu temel kavramı araştırmak, öğretmenlere sadece öğrencileri arasındaki farklı yorumlara açık olmaları gerektiğini değil, aynı zamanda öğrenciler ve öğretmenlerin aynı medyayı da aynı şekilde deneyimlemediklerini hatırlatır. Medya okuryazarlığının amacı, öğretmenin zihnindeki "doğru" yorumu ortaya çıkarmak değil, bir medya mesajının "kurgulanmışlığı" yoluyla öğrencilerin düşünmesine ve daha sonra onların yorumlarını kanıtlarla açıklamasına yardımcı olmaktır (CML, 2005).

Temel Kavram 4. İçerik ve Mesaj: Medyanın gizlenmiş değer ve görüşleri vardır.

Öğrencilerin sadece \%9'u tarafından dördüncü temel kavramla ilgili metaforlar üretilmiştir. Bu temel kavramın kapsamı; ideoloji, önyargı ve temsilde açık ve gizli olan çağrışımları sorgulamak için medya mesajlarının gerçek içeriğine odaklanmaktır. Bu temel kavrama yönelik çalışmalar medyadaki önyargıyı belirlemenin ötesinde, öğrencilerin tüm iletişimin öznel doğasını tanımasına yardımcı olur (Kellner ve Share, 2005).

Bir medya mesajının içeriğine baktığımızda, tüm medyanın, kimin ve neyin önemli olduğu hakkında ince mesajlar taşıdığını fark ederiz. Çünkü tüm medya mesajları seçimler yapılarak kurgulanmıştır. Bu seçimler kaçınılmaz olarak mesajı inşa edenlerin değerlerini, tutumlarını ve bakış açılarını yansıtır. Bir karakterin yaşı, cinsiyeti veya ırkıyla canlandırılan hayat tarzları, tavırları ve davranışları ile ilgili bir araya getirilen karar, bir ortamın seçilmesi (Kentsel? Kırsal? Zengin? Fakir?) ve olaydaki eylemler ve tepkiler bir TV şovunda, bir filmde veya bir reklamda değerlerin "gizli" olarak yerleştirilme yollarından bir kaç tanesidir. Haberlerde bile, hangi öykülerin ilk olarak sunulacağı, ne kadar uzun olacağı, hangi tür resimlerin seçileceğine ilişkin kararlarda da değerler gizli bir şekilde yerleştirilmiştir. 
Temel Kavram 4 ile ilgili önemli olan, fikirlerin ve değerlerin medya mesajlarında gizli olarak verilmesi değil, ana akım medyanın değerlerinin tipik olarak mevcut sosyal sistemi güçlendirdiğini ve dolayısıyla doğruladığını ifade etmemesidir. $\mathrm{Bu}$ nedenle açık ve gizli değerleri sorgulama ve rasyonel olarak tanımlama becerileri demokratik bir toplumda etkili vatandaşlık için hayati bir önem taşımaktadır (Jolls ve Thoman, 2008).

Temel Kavram 5. Güdü: Medyadaki mesajların büyük çoğunluğu kazanç ya da güç elde edebilmek için düzenlenmiştir.

Beşinci temel kavram, öğrencileri bu mesajın neden gönderildiğini ve nereden geldiğini sorgulamaya teşvik eder. Bu temel kavram çalışmaya katılan öğrencilerin \%26'sı tarafından ifade edilmiştir. Çoğu zaman öğrenciler, medyanın rolünün sadece eğlendirmek ya da bilgilendirmek olduğuna inanırlar (Kellner ve Share, 2005). Ancak dünyadaki kitle iletişim araçlarının büyük bir bölümü ticari işletmeler tarafından kurulmuştur ve bugün de ticari işletmeler olarak faaliyetlerine devam etmektedirler. Çoğu medya, bir şirkete kar sağlamak veya fikirleri değiştirmek gibi özel bir amaç için düzenlenmiştir. Şirketler en çok parayı reklâm ve pazarlamadan elde ederler. Reklam, kâr oluşturmanın en belirgin yoludur. $\mathrm{Bu}$ nedenle reklâmlar televizyon yayınlarının, gazete ve dergi sayfalarının büyük bölümünü oluşturmaktadırlar. Bu noktada pek çok insanın bilmediği şey, ticari medya yoluyla sadece reklâmı yapılan ürünün izleyiciye satılmadığı aynı zamanda izleyicilerin de reklâmı veren kuruluşa satıldığıdır. Televizyondaki programların ya da bir dergideki makalelerin asıl amacı, bir kitle yaratmak ve onları alıcı bir ruh haline sokmaktır. Böylece ağ ya da yayıncı, ürünlerin reklamını yapmak için sponsorlara zaman ya da alan satabilecektir. Buna "gözbebeklerini kiralamak" denir. Ayrıca internetin uluslararası bir platform haline gelmesiyle mesajla güdüleme meselesi dramatik bir şekilde değişmiş, gruplar ve örgütlerin - buna bireylerde dahil başkalarını olumlu ya da olumsuz, belirli bir bakış açısına ikna edebilecek güçlü araçlara erişebilmelerini sağlamıştır (Jolls ve Thoman, 2008).

Temel Kavram 5 kapsamında, bir medya mesajının para, ego ya da ideoloji tarafından etkilenip etkilenmediğinin incelenmesi hedeflenmektedir. Bir mesaja doğru şekilde cevap verebilmek için, bilgilendirici, ikna edici veya eğlendirici temel içerik motiflerinin ötesini görebilmemiz gerekir. Bu kapsamda bir medya metnini analiz ederken, öğrenciler kendilerine şu soruları sormalıdır: $\mathrm{Bu}$ mesajı kim ve neden yarattı? Bu içerik birilerine ne gibi faydalar sağlayabilir? Kimler için dezavantajlı olabilir? Medya içeriğinin, TV şovlarının, dergilerin veya İnternet sitelerinin, her yaştan izleyicileri ve okuyucularını, reklâm verenler için alıcı hedef kitlelere nasıl dönüştürdügünü keșfetmek, medya okuryazarlığı sınıfının en aydınlatıcı anlarını yaratır. Ayrıca, mesajın amacının incelenmesi, sahiplik konularını, toplumdaki medya kurumlarının yapısını ve etkilerini de ortaya çıkarmak için öğrencilere fırsatlar sunacaktır. (CML, 2005).

Çalışmada veri analizi sonucunda, Medya Okuryazarlığı Merkezinin belirlediği 5 temel kavramdan ayrı olarak iki yeni kategori daha oluşturulmuştur. Bunlardan ilki Kavram 6. "Medya sinırsızdır/enegellenemez"dir. Katılımclların \%15'i (f=11) medyanın dünya hakkında sınırsız kaynaklar sağladığını ve engellenemez olduğunu belirtmiştir. Medyanın engellenemez olmasına bir örnek olarak bir dönem Türk hükümetinin facebook'u kapatmasına karşılık buna alternatif olarak twitter kullanımının çok hızlı bir şekilde yaygınlaştığını söyleyebiliriz. Yine aynı şekilde 
Wikipedia'nın kapatılmasına rağmen farklı şekilde bu sunucuya ulaşım yolları keşfedilmiş ve erişim tamamen engellenememiştir. Denizyıldızı metaforunda da belirtildiği gibi medyada bir sosyal ağ engellendiğinde başka bir sosyal ağ kolayca oluşturulmaktadır.

Diğer kavram da; Kavram 7. Medya temel ihtiyaçlarımızdandır. Öğrencilerin \%8'i $(\mathrm{f}=6)$ medyayı temel ihtiyaç (hava, ekmek, su, vs.) olarak ifade etmektedirler ki bunu bir tür bağımlılık olarak yorumlayabiliriz. Bağımlılık, tıp ve davranış bilimlerinde ortaya çıkan bir kavramdır. Tıbbi anlamda, zihinsel ve fiziksel olarak belirli bir madde, özellikle de uyuşturucuya bağlı bir durum anlamına gelir. Tüketiciler sadece fiziksel bir maddeye değil aynı zamanda sorunlu bir davranışa da bağımlı olabilirler. Bazı araștırmacılar, bağımlılık kavramının sadece bir ilacın alınmasıyla ilgili vakalara uygulanması gerektiğini düşünürken çoğu bağımlılık kavramını belirli türdeki sorunlara uygularlar. Davranışlar her iki durumda da benzerdir. Bu madde dışı bağımlılık türleri davranışa yönelik bağımlılıklar olarak sınıflandırılır; Yeme bozukluğu, patolojik kumar oynama, video oyun bağımlılığı, bilgisayar bağımlılığı, televizyon bağımlılığı, alışveriș bağımlılığı gibi davranışlar örnek olarak gösterilebilir (Kim ve Kim, 2002). Literatürü gözden geçirdiğimizde de, son yıllarda İnternet Bağımlılığı Bozuklukları, Problemli İnternet Kullanımı, Patolojik İnternet Kullanımı, Aşırı İnternet Kullanımı, Siber Bağımlılık, Yüksek İnternet Bağımlılığı, Sanal bağımlılık gibi farklı kavramlarla ifade edimiş olsada problemli internet kullanımının arttığını görmekteyiz (Acier ve Kern, 2011).

Çalışmaya katılan öğrecilerin yapmış olduğu meteforlarda da görüldüğü gibi öğrencilerin Medya Okuryazarlığı Merkezinin belirlediği 5 temel kavram hakkında yeterli farkındalığa sahip olmadığını söyleyebiliriz. Bu çalışmanın bulgularına paralel olarak Özonur ve Özalpman (2009) Türk medya okuryazarlığ projesinin eleştirel medya okuryazarlığı yaklaşımının özellikle üzerinde durduğu medyanın mevcut yapısı, sahiplik ilişkileri, mesajların ne amaçla oluşturulduğu gibi konularda öğrenciyi kapsamlı bir şekilde bilgilendirmeye yönelik olmadığını vurgulamıştır. Bunun yanısıra bu çalıșmaya katılan öğrencilerin \%77'sinin medya okuryazarlığının eleștirel analiz becerisi olduğu konusunda hem fikir oldukları söylenebilir. Bu açıdan değerlendirdiğimizde medya okuryazarlığı öğrencilere eleștirel düşünme becerilerini geliştirmede yardımcı olan geniş bir laboratuar sunmaktadır (Thoman ve Jolls, 2008). Benzer șekilde Feurstein (1999) tarafından yürütülen bir araştırmada, medya okuryazarlığı derslerinin materyallerle desteklediği durumlarda, öğrencilerin medya okuryazarlığı ve eleştirel düşünme becerilerini arttırdığını ortaya koymuştur. Ayrıca, Arke (2005) medya okuryazarlığı ve eleştirel düşünme arasında önemli bir ilişki olduğu bulgusuna ulaşmıștır. Arke için, medya okuryazarlığı eğitimi bireylerin eleştirel düşünmelerini sağlamakaçısından önemli bir araçtır. Thoman ve Jolls (2008) tarafından medya okuryazarlığı derslerinde beş anahtar soruya odaklanmanın medyanın nasıl oluşturulduğunu ve amaçlarının neler olduğunu derinlemesine anlamaya yol açacağı belirtilmiştir.

\section{Sonuç ve Öneriler}

UNESCO medya eğitimini, 21. yüzyılda kültürel eğitimin gelişiminde bir öncelik olarak tanımlamaktadır. Medya eğitimi alanında ilk hareket Fransa, İngiltere ve Rusya'da 1920'lerde başlamıştır. Günümüzde de medya eğitimi pek çok ülke için önemlidir. İngiltere ve Fransa medya ve iletişim ile bilgi teknolojileri eğitimi alanında Avrupa'daki en aktif ülkelerdir. Kanada, Avustralya ve ABD'de medya eğitimi 
konusunda gelişme gösteren ülkelerdir. Örneğin; İngiltere'de 1930’larda başlayan medya eğitimi 2000'li yıllarda, ulusal eğitim programında zorunlu hale gelmiştir. Medya eğitimi yılda bir veya iki haftayı kapsamaktadır ve daha gelişmiş medya kültürü eğitimleri müfredatın \% 8' ini kapsamaktadır (Federov, 2008). Ayrıca İngiltere'de medya eğitiminin sorunlarıyla ilgili bir takım kuruluşlar vardır. 1933 yılında hükümet tarafından kurulan British Film Enstitüsü bunlar arasındadır. Enstitünün Eğitim bölümü yıllardır öğretmenler için konferanslar, seminerler, çalıştaylar düzenlemekte, araştırmalar yapmakta ders kitapları ve öğretim kılavuzları yayınlamaktadır. Fransa'da ise CLEMI (Centre de Liaison de l'enseignement et des medias d'indormation) olarak adlandırılan eğitim ve bilgi medyasını bağdaştıran bir merkez bulunmaktadır. Bu merkez Fransız Eğitim Bakanlığı'nın bir parçasıdır ve gazetelerden internete kadar her tür medya üzerinde çalışmaktadır. Medya okuryazarlığı hakkında teknik veya tüketici yaklaşımı yerine vatandaşlık yaklaşımı geliştirmek ve aynı zamanda medyanın eleştirel anlayıșını ve aktif katılımı geliştirmek üzerine yoğunlaşmıştır. $\mathrm{Bu}$ yüzden gençlerin okullarda medyayı geliştirmelerine ilişkin projelerini desteklemektedir. CLEMI'nin özelliği medya profesyonelleriyle güçlü ortaklıklar kurmuş olmasıdır. Her sene okullarda ulusal basın ve medya haftası düzenleyerek gençleri, eğitimcileri ve medya profesyonellerini biraya getirmektedir. Aynı zamanda medya profesyonelleri eğitimler, toplantılar ve araştırma projeleri düzenlemektedir. Aile dernekleriyle de çalışılarak, aileler bilgilendirilmektedir. Bu birimin temel faaliyetleri öncelikle öğretmenleri eğitmektir. İkinci olarak, okullar arasında gazete çıkarmak, TV programı yapmak, siber gazeteler hazırlamaktır. Aynı zamanda kitap, DVD, CD-ROM vb pedagojik araçlar yayınlamaktadırlar (Bevort, 2006).

Avrupa'nın medya eğitimindeki başarılarına rağmen Kanada 10- 15 yıldır liderliği elinde bulundurmaktadır. En azından medya kültürü İngiliz dili müfredatlı okulların önemli parçasıdır. Medya ve bilgi teknolojileri eğitimleri tüm Kanada Üniversiteleri'ndeverilmektedir. Bütün Kanada vilayetlerindemedya eğitimibirimleri eylemcileri mevcuttur ve bunlar konferanslar düzenlemekte, süreli ve süresiz yayınlar yapmaktadır. Kanada Medya Eğitimi Birliği (CAME) öğretmenler için yaz kursları organize etmekte ve öğretim kılavuzları ve programları yayınlanamaktadır. Kanada'da medya kültürü çalışmaları 1'den 12. sınıfa kadar zorunlu ders olarak okutulmaktadır. Bugün Kanada'daki medya eğitimi gelişmeye devam etmekte ve dünyadaki liderliğini sürdürmektedir.

ABD’de medya okuryazarlığı hareketi, büyük ölçüde medya okuryazarlığı eğitimini profesyonel konferanslar ve medya hizmetleriyle ilerleten, iletişim ağl olușturan ve bilgi alışverişi sağlayan iki ulusal kuruluş olan Amerikan Medya Okuryazar Birliği (AMLA) ve Medya Eğitimi Koalisyon Hareketi (ACME) tarafından yürütülmektedir. Medya Eğitimi Unsurlarını içeren 4 müfredat kategorisi şu şekilde belirlenmiştir: İngilizce, Dil ve İletişim Sanatları, Sosyal Çalışmalar, Tarih ve Yurttaşlık Bilgisi, Sağlık, Beslenme ve Tüketicilik ve Medya Uygulamaları (Guo-Ming, 2007).

Çoğu ülkede medya okuryazarlığı geçtiğimiz yüzyılın ortalarından beri önemle üzerinde durulan bir konu iken Türkiye, medya okuryazarlığı eğitiminde daha yolun başındadır. Medya okuryazarlığının erken yaşlardan itibaren başlayarak hayat boyu geliștirilecek bir beceri olması, verilecek eğitimin de okul öncesinden başlayarak yetişkin eğitimine uzanan bir sürece yayılmasını gerekli kılmaktadır. $\mathrm{Bu}$ açıdan Türkiye'de medya okuryazarlığı eğitiminin; sadece ilköğretimin ikinci 
kademesine sıkıştırılması, haftada iki saat olması, üstelik seçmeli olması, dersi veren öğretmenlerin bu konuda yeterli eğitim almamış olması, ders malzemelerinin yetersizliği hayat boyu geliștirilmesi gereken bir medya okuryazarlığı eğitiminin gereklerini karşılamaktan uzak görünmektedir (Şeylan, 2008; Altun, 2009; Akşit ve Yıldız, 2010; Toker, 2010; Hasdemir, 2012; Solmaz,2016). İnceoğlu (2008), Çetinkaya, (2008) ve Akyürek (2007), medya okuryazarlığı eğitiminde en tartışmalı olan ve üzerinde en çok düşünülmesi gereken konunun, bu dersin iletişim disiplinine dair hiçbir alt yapıya sahip olmayan Sosyal Bilgiler öğretmenleri tarafından verilmesi olduğunu ifade etmişlerdir. Benzer şekilde Özonur ve Özalpman (2009) tarafından Türk medya okuryazarlığı projesinin şimdilik sektörün desteğinden uzak olmakla birlikte ticari medya okuryazarlığı yaklaşımına yakın bir konumda, bilinçli ve aktif birer çocuk-tüketici yaratmaya doğru ilerlediğini belirtmişlerdir.

Farklı ülkelerin medya okuryazarlığı eğitim programları incelendiğinde, medya eğitiminin ya farklı bir ders (Medya Uygulamaları) olarak ya da var olan birçok dersin (İngilizce, Dil ve İletişim Sanatları, Sosyal Çalışmalar, Tarih ve Yurttaşlık Bilgisi, Sağlık, Beslenme ve Tüketicilik) kapsamında zorunlu olarak verildiği görülmektedir. Oysa Türkiye'de bu ders seçmeli olarak okutulmaktadır. Bu dersin zorunlu ders olarak okutulması hatta sosyal bilgiler, tarih, fen ve teknoloji, yabancı dil eğitimi, sağlık bilgisi, vatandaşlık eğitimi gibi derslerle bütünleştirilerek verilmesi daha uygun olacaktır (Altun, 2009; Akşit ve Yıldız, 2010). Ayrıca ticari kaygı gütmeyen kurumlarca medya okuryazarlığına yönelik kitaplar ve sesli-görsel ders materyalleri, konferanslar, seminerlerle öğretmen, öğrenci ve ailelerin desteklenmesi gerekir (Yıldız ve Akşit, 2012). Örneğin; Amerika'da Link TV'de Haberleri Anlama Projesi öğrencilere yayın haberlerini remix yapma, dil, görüntü ve düzenleme seçeneklerinin anlam oluşturma sürecini nasıl şekillendirdiğini keşfetme olanağı sağlamaktadır. New York Times Öğrenme Ağı, yıllık ders programına paralel olarak hazırlanmış öğretmen ve öğrencilerin haberleri yorumlamalarına yardımcı olacak 3.000'den fazla ders planı ve aktivite sunmaktadır. Red Lasso (www.redlasso.com) gibi video haber toplama hizmetleri, yerel TV haber içeriklerinin alıntılarını özel ya da kamusal amaçlı olarak seçme, düzenleme ve yayma, 150'den fazla medya pazarından yerel haber kliplerini seçme ve yerleştirme olanağl sağlar. News Trust (www.newstrust. com), kullanıcıların, başkalarının basılı haber medyası raporlarının bilgi içeriğini nasıl değerlendirdiğini görmelerini sağlamak için bir haber derecelendirme sistemi kullanmaktadır. Bu tür çalışmalar, eğitimcileri ve öğrencileri, yeni çevrimiçi kaynaklar kullanarak yerel haberlerle etkileşimde bulunmanın yeni yollarını keşfetmeleri için güçlendirecektir (Hobbs, 2010).

Hobbs ve Jensen (2009) medya okuryazarlığı eğitimcilerinin, öğrencilerinin kendini ifade etme, savunma ve eğitim için tüm dijital medya ve teknoloji araçlarını kullanarak medya mesajlarının aktif yazarları olmasına yardımcı olmaları gerektiğini savunmuştur. Ayrıca, medya okuryazarlığı eğitimcilerinin kitle iletişim araçları, popüler kültür ve dijital medyalarla dolu bir dünyada büyüme deneyiminin merkezindeyer alan sorunları çözmeye devam etmelerigerektiğini belirtmiştir. Haber ve reklam analizini öğrenmek, müziğin toplumsal işlevlerini incelemek, propaganda, görüş ve bilgileri birbirinden ayırt etmek, eğlence ve bilgi medyasında cinsiyet, ırk ve sınıfın nasıl temsil edildiğini incelemek, medya ekonomisini ve mülkiyetini anlamak, şiddet ve cinselliğin medya mesajlarında nasıl tasvir edildiğini araştırmanın yaşam becerileri olmaya devam ettiğini vurgulamıștır. Benzer şekilde Kellner ve Share'de 
(2007) dijital medyanın ortaya çıkışı ile birlikte, kişisel ve sosyal kimlik, özel olanla kamuya açıklar arasındaki karmaşık etkileşimi, yasal ve etik sorunları göz önüne almamız gereken önemli yeni medya okuryazarlığı becerilerine gerek olduğunu vurgulamıştır. Ayrıca medya eğitiminin, öğrencilerin kendi toplumlarında bilgi sahibi ve katılımcı medya okuryazarı olmaya teşvik edildiği demokrasi eğitimi ile bağlantılı olması gerektiğini ifade etmiştir. Bu nedenle eleştirel medya okuryazarlığı bilgi okuryazarlığı, teknolojik okuryazarlık, sanat ve sosyal bilimler ile eğitimin demokratik yeniden yapılandırılmasıyla bağlantılı olmalıdır. Eleştirel medya okuryazarlığı, iletişim ve toplumla ilgilendiği için tüm müfredat alanlarında çalıșılan ortak bir konu olmalıdır.

Sonuç olarak, Hobbs'un (2010) da belirttiği gibi medya okuryazarlığı eğitimi, öğretecek bilgi ve becerilere sahip öğretmenler olmadan gerçekleşemez. Hobbs (2010) günümüzde, birçok eğitimcinin, medya okuryazarlığı öğretim uygulamalarına aşina olmadığını ve bunun okullarda liderlik açığı yarattığını belirtmiştir. Ayrıca çoğu Eğitim Fakültesinin, dijital medyayı aktif olarak kullanmadığından dolayı, öğrencilerine yenilikçi dijital ve medya okuryazarlığı eğitimi sunmakta yetersiz kaldığını vurgulamıştır. İletişim Fakültelerinin çoğunun da, profesyonel dijital medya eğitiminde uzmanlaşmış, ancak çocukların, gençlerin ihtiyaçlarını karşılayan programların geliştirilmesinde daha az uzmanlığa sahip olduğunu belirtmiștir. Bu nedenle Eğitim ve İletişim Fakülteleri arasında bu ders kapsamında disiplinler arası işbirliğinin yapılması ve her iki fakültenin öğrencilerinin birlikte çalışması dersin kalitesini de arttıracaktır. Ayrıca bu iki fakültenin birlikte, öğretmenlerin profesyonel gelişimleri için sertifika programları geliştirmeleri de bir alternatif olabilir.

\section{Kaynakça}

Acier, D \& Kern, L.(2011). Problematic Internet use: Perceptions of addiction counsellors, Computers \& Education 56, 983-989

Akşit F. ve Yıldız F. (2010). Assessment Of The Current And The Future Of Media Literacy Education In Turkey. The Second International Congress of Educational Rerearch, 1268-1292.

Akyürek, Z. (2007). Media Literacy in Turkey. Yeditepe Üniversitesi Sosyal Bilimler Enstitüsü, İstanbul: Yayınlanmamış lisans tezi.

Altun, A. (2008). Türkiye'de Medya Okuryazarlığı, İlköğretmen Eğitimci Dergisi, Cilt 16 http://www.sosyalbilgiler.gazi.edu.tr/article21.pdf

Altun, A. (2009). Eğitim Bilim Açısından Seçmeli Medya Okuryazarlığı Dersi Programına Eleştirel Bir Yaklaşım, Ahi Evran Üniversitesi Eğitim Fakültesi Dergisi, 10 (3),97-109

Ang, I. (2002). On the politics of empirical audience research. In M. G. Durham \& D. M. Kellner (Eds.), Media and cultural studies key works (pp. 177_/197). Malden: Blackwell.

Arık, B. (2006). "Medya Okuryazarlığı” I. Bölüm Medya Okuryazarlığı - Temel Bir Aktör Olarak Medyanın Rolü, RTÜK, Ankara.

Arke, E. T. (2005). Media literacy and critical thinking: is there a connection? (Unpublished doctoral dissertation), Duquesne University, Pittsburg. 
Center for Media Literacy (2005). Five Key Questions of Media Literacy, http://www. medialit.org/sites/default/files/14B_CCKQPoster+5essays.pdf

Creswell, W. J. (2013). Nitel Araştırma Yöntemleri Beş Yaklaşıma Göre Nitel Araștırma ve Araştırma Deseni (Çev. Mesut Bütün, Selçuk Beşir Demir) Siyasal Kitabevi, Ankara

Çetinkaya, S. (2008). Bilinçli Medya Kullanıcıları Yaratma Sürecinde Medya Okuryazarlığının Önemi. Ankara Üniversitesi Sosyal Bilimler Enstitüsü, Ankara: Yayınlanmamış yüksek lisans tezi

Fedorov, A. (2008). "Media Education Around The World: Brief History" Acta Didactica Napocensia, Volume 1, Number 2

Fedorov, A. (2015). Media Literacy Education. Moscow: ICO "Information for all", http://www.ifap.ru/library/book564.pdf

Feurstein, M. (1999). Media literacy in support of critical thinking, Journal of Educational Media, 24(1), 43-54.

Guo-Ming, C. (2007). Media (Literacy) Education in the United States, China Media Research, 3(3) http://www.chinamediaresearch.net/vol3no3/10_Guo_Ming_ Chen.pdf

Hall, S. (1980). Encoding/decoding. In S. Hall, D. Hobson, A. Lowe \& P. Willis (Eds.), Culture, media, language (pp. 128_/138). London: Hutchinson.

Hasdemir, T. (2012). Gelenekselden Yeni Medya Okuryazarlığına: Türkiye Örneğinde Bir Değerlendirme, Hitit Üniversitesi, Sosyal Bilimler Enstitü Dergisi, 5 (2), 23-40)

Hobbs, R. (2010). Digital and Media Literacy: A Plan of Action, by The Aspen Institute Communications and Society Program, https://files.eric.ed.gov/fulltext/ ED523244.pdf

Hobbs, R. ve Jensen, A. (2009). The Past, Present, and Future of Media Literacy Education, The National Association for Media Literacy Education's Journal of Media Literacy Education 1, 1-11

Hobbs, R. Çev: Bağlı, M. T. (2004). "Medya Okuryazarlığı Hareketinde Yedi Büyük Tartışma”, Ankara Üniversitesi Eğitim Bilimleri Fakültesi Dergisi, yıl: 2004, cilt: 37 , sayı: 1, s.122-140

İnceoğlu, Y. (2007). "Medya Okuryazarlığı: Neden Gerekli” Medya Okuryazarlığı Ed. N. Türkoğlu ve M. Cinman Şimşek Kalemus Yayıncılık, ISBN 978-975-016102-5, İstanbul.

Jolls\&Tessa.(2012).MediaLiteracy:ASystemforLearning Anytime,Anywhere.Accessed on January 20, 2014. Los Angeles: Center for Media Literacy. http://www. medialit.org/sites/default/files/eBookDeconstructionConstruction2012.pdf

Kellner, D. \& Share, J. (2005). Toward Critical Media Literacy: Core concepts, debates, organizations, and policy, studies in the cultural politics of education, 26 (3), pp369-386

Kellner, D. \& Share, J. (2007).Critical medialiteracy, democracy, and the reconstruction of education. In D. Macedo \& S.R. Steinberg (Eds.), Media literacy: A reader (pp. 3-23). New York: Peter Lang Publishing. 
Kıncal, R., Kartal, Y. ve Yılmaz O. (2009). Medya Okuryazarlığı Eğitimi, Milli Eğitim Dergisi, (181):318-333

Kim, S., ve Kim, R. (2002). A study of internet addiction: status, causes, and remedies. Journal of Korean Home Economics Association English Edition, 3(1), 1-19.

Masterman, L. (1994). A rationale for media education (1st Part). In L. Masterman \& F. Mariet (Eds.), Media Education in 1990s Europe (pp. 5-87). Strasbourg, France: Council of Europe.

Oxstrand, B. (2009). Media Literacy Education- A discussion about Media education in the Western countries, Europe and Sweden, Paper presented at the Nordmedia09 conference in Karlstad University,

Özonur, D. ve Özalpman, D. (2009).Türkiye'de Medya Okuryazarlığı Projesi Üzerine Bir Değerlendirme, Marmara İletişim Dergisi, 15

Patton, Q.M., (2014) Nitel Araștırma ve Deerlendirme Yöntemleri (Çev. Mesut Bütün, Selçuk Beşir Demir) Pegem Akademi, Ankara.

Pekman C. (2007) “ Avrupa Birliği Çevre Politikalarında Katılım Hakkı: Aarhus Sözleşmesi” Medya Okuryazarlığı Ed. N. Türkoğlu ve M. Cinman Şimşek Kalemus Yay. s.40, ISBN 978-975-01610-2-5, İstanbul

Solmaz, T. (2016). Yeni İletişim Teknolojileri Bağlamıda Medya Okuryazarlığı, Atatürk Üniversitesi, Sosyal Bilimler Enstitüsü Radyo Tv Ve Sinema Anabilim Dalı, Yayınlanmamış Yüksek Lisans Tezi

Şeylan, Seher (2008). Medya Okuryazarlığı Ders Uygulamalarında Dünya Üzerinde Görülen Aksaklıklar, T.C. İstanbul Kültür Üniversitesi, Sosyal Bilimler Enstitüsü, İstanbul, Yayınlanmamış yüksek lisans tezi

Thoman, E. ve Jolls T. (2008). 21. Yüzyıl Okuryazarlığı. (Çev. Cevat Elma ve Alper Kesten) Ekinoks Yayınları, ISBN 978-994-449-513-4, Ankara http://www.kff. org/entmedia/upload/Key-Facts-Media-Literacy.pdf

Toker-Erdoğan, M. (2010), Toplumsal Cinsiyet Eşitliğinin Sağlanmasında Medya Okuryazarlığının Rolü, Uzmanlık Tezi, Prof. Dr. Mutlu Binark (danışman), Ankara: T.C. Başbakanlık Kadının Statüsü Genel Müdürlüğü.

Türkoğlu, N. (2007). İletişim Bilimlerinden Kültürel Çalışmalara Toplumsal İletişim. Tanımlar, Kavramlar, Tartışmalar, İstanbul: Kalemus Yayınları, ISBN 978-97501610-2-5, İstanbul.

Yıldırım, A. ve Şimşek, H. (2013). Sosyal Bilimlerde Nitel Araştırma Yöntemleri, Seçkin Yayıncılık, Ankara

Yıldız F \& Akşit, F (2012), Social Studies Teacher Candidates Perceptions about Media Literacy, Procedia Social and Behavioral Sciences, Volume 46, 2012, Pages 4897-4901, doi:10.1016/j.sbspro.2012.06.356 
